Marcin Drewek

Uniwersytet Mikołaja Kopernika, Toruń

drewek@umk.pl

\title{
Mariusz Bidziński, Marek Chmaj, Bogusław Uliasz, Ustawa o wstrzymaniu sprzedaży nieruchomości rolnej Zasobu Wtasności Rolnej Skarbu Państwa - aspekt konstytucyjnoprawny, Wydawnictwo Adam Marszałek, Toruń 2017, ss. 247
}

DOI: http://dx.doi.org/10.12775/SIT.2017.045

Recenzowana publikacja stanowi pierwsze opracowanie o charakterze monograficznym odnoszące się do uchwalonej niedawno ustawy o wstrzymaniu sprzedaży nieruchomości rolnej Zasobu Własności Rolnej Skarbu Państwa oraz nowelizacji kilku innych ustaw (tzw. ustawa wstrzymująca) ${ }^{1}$. Dotyka doniosłej dla praktyki obrotu prawnego kwestii zgodności wskazanej ustawy z Konstytucją.

Opracowanie ma charakter bardziej monografii niż komentarza do ustawy wstrzymującej. We wstępie recenzowanej publikacji wskazano, że jej celem było stworzenie asumptu do dyskusji nad aktualnym kształtem ustawy wstrzymującej oraz potrzebą jej nowe-

\footnotetext{
${ }^{1}$ Ustawa $z$ dnia 14 kwietnia 2016 r. o wstrzymaniu sprzedaży nieruchomości Zasobu Własności Rolnej Skarbu Państwa oraz o zmianie niektórych ustaw (Dz.U. z 2016 r. Poz. 585 ze zm.).
} 
lizacji. Publikacja stanowi zdecydowanie krytyczny głos wskazujący, że wiele spośród przepisów tej ustawy powinno być uznanych za niekonstytucyjne. $Z$ poglądami wyrażonymi w monografii (w kwestii konstytucyjności poszczególnych przepisów) można polemizować, odnotować natomiast należy, że na poparcie swojego stanowiska Autorzy zasadniczo przytoczyli liczne argumenty, czerpiąc z dorobku doktryny oraz orzecznictwa Trybunału Konstytucyjnego.

We wprowadzeniu do recenzowanej publikacji Autorzy wskazali, że została wzbogacona o refleksję natury cywilnoprawnej. Celem niniejszej recenzji jest odniesienie się do poruszanych w monografii kwestii cywilistycznych. $Z$ tego punktu widzenia do najistotniejszych rozdziałów należą, jak się wydaje, pierwszy, trzeci oraz czwarty². $Z$ uwagi na fakt, że nie jest możliwe odniesienie się $w$ recenzji do wszystkich interesujących kwestii poruszonych przez Autorów, ograniczyć się należy do analizy wybranych zagadnień zawartych we wskazanych rozdziałach.

$\mathrm{W}$ rozdziale pierwszym przedstawiono kwestie odnoszące się do procesu legislacyjnego oraz najistotniejszych zmiany wprowadzonych przez tzw. ustawę wstrzymującą. Opisano wprowadzone zmiany i opatrzono je krótkim (zasadniczo krytycznym) komentarzem. Przyjęta sekwencja prezentowanej materii nie budzi zastrzeżeń.

W monografii wskazano w szczególności na treść wprowadzonego ustawą przepisu art. 166 § 3 k.c. (dotyczącego prawa pierwokupu), który znacznie ogranicza krąg podmiotów i swobodny wybór kontrahenta przez właściciela. Zasadnie poddano wskazaną regulację krytyce. Poza podniesionymi przez Autorów kwestiami można wskazać, że pewne wątpliwości budzi także zagadnienie wyceny nieruchomości - realizacja prawa pierwokupu następuje nie po cenie swobodnie kształtowanej przez rynek, ale określonej przez Agencję, co (mimo kontroli sądowej) ogranicza swobodę obrotu. W doktrynie podkreśla się ponadto, że nowa regulacja prawa pierwokupu nastręcza licznych wątpliwości w kwestii zbiegu z prawem pierwokupu przysługującemu innym niż Agencja podmiotom czy

${ }^{2}$ Wiele cywilistycznych zagadnień znalazło się także w rozdziale V, jednak w sporej mierze zostały poruszone również w poprzednich rozdziałach. 
w kwestii relacji prawa pierwokupu do prawa nabycia przy zawarciu warunkowej umowy sprzedaży ${ }^{3}$. Wbrew obawom wyrażonym w monografii należy jednak uznać, że w praktyce Agencji rzadko będzie przysługiwało prawo pierwokupu, skoro nabywcą nieruchomości rolnej może być zasadniczo tylko rolnik indywidualny ${ }^{4}$.

Odniesiono się również do znowelizowanego przepisu art. 172 § 3 k.c., formułując tezę, że ograniczenie kręgu podmiotów mogących zasiedzieć nieruchomość rolną w nieuzasadniony sposób różnicuje podmioty zasiadujące nieruchomość, co może być niezgodne $z$ Konstytucją. Nieco zbyt ogólne wydaje się przy tym stwierdzenie, że zasiedzenie jest przejawem korzystania z prawa własności, a wskazany przepis ingeruje w zakres ochrony tego prawa. Należałoby uściślić, że zasiedzenie jest sposobem nabycia prawa własności, jednak odbywa się ze szkodą dla interesu dotychczasowego właściciela, na korzyść osoby, której nie przysługiwało prawo własności, a jedynie posiadanie samoistne. Nie jest też do końca jasne, dlaczego na poparcie omawianej tezy powołano się wyłącznie na poglądy doktryny brytyjskiej (strona 32 oraz przypis 38), zamiast judykatury i nauki polskiej ${ }^{5}$, tym bardziej, że uregulowania dotyczące prawa własności w systemie common law różnią się w pewien sposób od założeń przyjętych przez system polski (civil law) ${ }^{6}$.

${ }^{3}$ Szerzej na ten temat zob. np.: R. Morek, Komentarz do art. 166 k.c., w: Kodeks cywilny. Komentarz. Zobowiązania. Część szczegótowa, t. III B, red. K. Osajda, Warszawa 2017, wersja elektroniczna; J. Grykiel, Ograniczenia obrotu nieruchomościami rolnymi oraz prawami udziałowymi $w$ spółkach po nowelizacji ustawy o kształtowaniu ustroju rolnego, „Monitor Prawniczy” 2016, nr 12 , s. 633-635.

${ }^{4}$ Szerzej na ten temat zob. np.: A. Suchoń, Komentarz do art. 10701 k.c., w: Kodeks cywilny, t. II: Komentarz. Art. 450-1088, red. M. Gutowski, Warszawa 2017, wersja elektroniczna; W. Borysiak, Komentarz do art. 10701 k.c., w: Kodeks cywilny. Komentarz.

${ }^{5}$ Zob. np. wyrok SN z 15 czerwca 2016 r., II CSK 639/15, Legalis nr 1482664; postanowienie SN z 19 września 2013 r., I CSK 735/12, Legalis nr 924878; A. Stelmachowski, K. Zaradkiewicz, w: System prawa prywatnego. Prawo rzeczowe, t. III, red. E. Gniewek, Warszawa 2013, s. 220-336; J. Ignatowicz, K. Stefaniuk, Prawo rzeczowe, Warszawa 2012, s. 41-65.

${ }^{6}$ Szerzej odnośnie do podstawowych założeń dotyczących prawa własności w prawie brytyjskim zob. np.: R. J. Smith, Property Law - Longman Law Series, Harlow 2011, s. 1-57; J. A. MacKenzie, M. Philips, Textbook on Land 
Rację mają natomiast autorzy, że wprowadzone rozwiązanie nie wydaje się w pełni przemyślane. $\mathrm{W}$ piśmiennictwie krytycznie odniesiono się do kwestii ograniczenia skuteczności zasiedzenia nieruchomości rolnych, co powoduje pewną dekompozycję instytucji zasiedzenia oraz nie jest spójne $z$ funkcją zasiedzenia. Dodatkowo podnosi się, że wprowadzony przez ustawodawcę okres przejściowy nie został należycie dostosowany do potrzeb obrotu prawnego ${ }^{7}$.

Kolejne kwestie cywilnoprawne omówiono rozdziale trzecim, odnoszącym się do kwestii znowelizowanego prawa pierwokupu. W tym miejscu pojawia się postulat połączenia podrozdziałów 1 i 2.1 poprzez odesłanie do bogatej literatury i orzecznictwa dotyczących ogólnej regulacji prawa pierwokupu i poświęcenie uwagi wyłącznie zmianom wprowadzonym przez ustawę wstrzymującą.

Należy odnotować, że w kilku miejscach w monografii można spostrzec, że autorzy trafnie wskazują na istotny problem dotyczący zgodności ustawy wstrzymującej z Konstytucją, jednak poprzestają na zasygnalizowaniu kwestii, bez jej szerszego omówienia. Niekiedy przytoczone informacje są zaczerpnięte $z$ dorobku doktryny i orzecznictwa Trybunału Konstytucyjnego, acz bez ich bezpośredniego przełożenia na kwestię zgodności poszczególnych regulacji z Konstytucją. Przykładowo wskazano, że podstawą ustroju rolnego państwa jest gospodarstwo rodzinne, państwo zaś powinno czynić starania celem wspierania rozwoju obszarów wiejskich, jednak nie odniesiono się szerzej do tej kwestii ${ }^{8}$. $Z$ przyczyny braku szerszej analizy cel przytoczenia tego fragmentu nie jest jasny, gdyż można go poczytywać zarówno jako wyraz aprobaty, jak i dezaprobaty dla wprowadzonych ustawą wstrzymującą zmian. W przeważającej części monografii następuje jednak bardzo bogata i szczegółowa analiza zapowiedzianych problemów.

Nie w pełni przekonuje podniesiony w recenzowanej monografii problem wielości odesłań odnoszących się do prawa pierwokupu.

Law, Oxford 2014, s. 1-35; M. Dixon, Modern Land Law, Oxon-New York, 2014, s. 1-27.

${ }^{7}$ Szerzej na ten temat zob. np.: R. Morek, op. cit.; J. Kępiński, Komentarz do art. 172, w: Kodeks cywilny, t. II.

${ }^{8}$ Zob. strona 73 oraz przypis 22 recenzowanej monografii. Podobne sytuacja np. strony 81-82, 91, 92, 93, 148 . 
Ustawodawca w treści regulacji ogólnej prawa pierwokupu odsyła do uregulowań zawartych w ustawach szczególnych (art. 596 k.c.). Analogicznie w treści ustawy wstrzymującej (zmieniony art. 3b pkt 5 ustawy o kształtowaniu ustroju rolnego) zawarte jest odesłanie, by w zakresie nieuregulowanym tą ustawą stosować przepisy ogólne zawarte w kodeksie cywilnym. W monografii krytycznie oceniono taką sytuację, podnosząc, że może ona powodować liczne negatywne konsekwencje dla obrotu prawnego. Racje mają Autorzy, że dostrzeżona kwestia powielenia odesłań stanowi superfluum i jest wyrazem niedbałości legislacyjnej ustawodawcy. Jak się jednak wydaje, nie nastręcza ona większych problemów jurydycznych z uwagi na zasadę lex specjalis derogat legi generali. Oba omawiane przepisy nakazują bowiem stosować najpierw regulację ustawy wstrzymującej, a w pozostałym zakresie przepisy kodeksu cywilnego.

Bardzo istotne znaczenie dla obrotu prawnego ma natomiast dostrzeżona przez autorów kwestia oceny ograniczenia przez ustawodawcę katalogu podmiotów mogących nabywać nieruchomości rolne w kontekście konstytucyjnej zasady bezstronności. Podniesiono ważkie argumenty, mogące świadczyć o potrzebie poszerzenia przyjętego w nowelizacji katalogu o dzierżawców i rolnicze spółdzielnie produkcyjne. Trafnie zwrócono przy tym uwagę, że działania podejmowane przez dzierżawców mogą pomagać w rozwoju rynków lokalnych. Można by dodać, że dzierżawcy nie zawsze będą zainteresowani prowadzeniem działalności rolniczej na dzierżawionej nieruchomości. Bardzo często celem będzie przykładowo rozwój energetyki odnawialnej poprzez wybudowanie i eksploatację elektrowni wiatrowych ${ }^{9}$.

Trafnie dostrzeżono również problemy związane $z$ wprowadzonym nowelizacją prawem pierwokupu udziałów i akcji. Wskazano zwłaszcza na kwestie uzyskania pakietu kontrolnego, nabycia akcji w sytuacji gdy nieruchomość rolna stanowi tylko niewielki odsetek

${ }^{9}$ Szerzej na ten temat zob. np.: wyrok SN z 5 października 2012 r., IV CSK 244/12, „Orzecznictwo Sądu Najwyższego. Izba Cywilna” 2013, nr 5, poz. 64, str. 54 z glosami: Ł. M. Wyszomirskiego, „Orzecznictwo Sądów Polskich” 2013, nr 10, s. 686, Z. Kuniewicza i S. Słotwińskiego, „Przegląd Prawa Rolnego” 2013, nr 2, s. 190 oraz M. Drewka, „Monitor Prawniczy” 2016, nr 14, s. 779. 
posiadanych gruntów oraz kwestię zachowania udziałów lub akcji mimo wyzbycia się nieruchomości rolnej. Dodatkowe rozważania $\mathrm{w}$ tej mierze zostały zawarte $\mathrm{w}$ rozdziale piątym, przy czym stanowią częściowo powtórzenie argumentacji już wcześniej poruszonej.

Omawiana kwestia nabycia udziału lub akcji budzi szereg kontrowersji w piśmiennictwie. Dostrzega się w szczególności problem objęcia prawem pierwokupu zakupu akcji dokonanego w celu umorzenia, problem ujęcia w katalogu podmiotowym jedynie polskich spółek handlowych (brak uwzględnienia np. spółdzielnie czy spółek zagranicznych), problem pominięcia sytuacji gdy spółka nie jest bezpośrednim (a jedynie pośrednim) właścicielem udziałów lub akcji czy tez problem wyceny wartości akcji ${ }^{10}$.

Autorzy trafnie wskazali ponadto na wątpliwości, jakie może budzić przysługujące agencji prawo do przeglądania ksiąg i dokumentów. Rozważania poczynione w recenzowanej monografii można wzbogacić o dostrzeżone w doktrynie problemy. W szczególności podnosi się, że ustawodawca określił zbyt krótki termin (1 miesiąc), który nie wystarcza w wielu wypadkach na należyte zapoznanie się $\mathrm{z}$ treścią dokumentów, tym bardziej że termin ten zawity ${ }^{11}$. Podkreśla się ponadto, że w ustawie wstrzymującej nie przewidziano żadnej sankcji za nieudostępnienie dokumentów w terminie ${ }^{12}$.

Rozdział czwarty dotyczy kwestii zmian wprowadzonych nowelizacją w zakresie umowy sprzedaży oraz umowy dzierżawy nieruchomości rolnych, głównie w ujęciu konstytucyjnoprawnym. $Z$ uwagi na różnice między tymi umowami zasadne byłoby omówienie ich w odrębnych rozdziałach. Podobnie jak w rozdziale poprzednim warto postulować pominięcie opisu ogólnej regulacji umowy sprzedaży oraz umowy dzierżawy i skupić się na kwestiach zmian wprowadzonych ustawą wstrzymującą. Natomiast zasadniczo w rozdziale

${ }^{10}$ Szerzej na ten temat zob. odpowiednio: J. Bieluk, Ustawa o kształtowaniu ustroju rolnego. Komentarz, Warszawa 2016, wersja elektroniczna, komentarz do art. 3 a; J. Grykiel, op. cit., s. 628-629 oraz 638-639.

${ }^{11}$ Szerzej na ten temat zob. np.: J. Bieluk, op. cit., komentarz do art. 3 a; J. Grykiel, op. cit., s. 638.

12 Szerzej na ten temat zob. np. P. Szymczyk, Nabywanie nieruchomości rolnych $w$ świetle nowelizacji przepisów o kształtowaniu ustroju rolnego, cz. II, „Nieruchomości” 2017, nr 4, s. 20; J. Bieluk, op. cit., komentarz do art. 3 a. 
czwartym utrzymuje się spójna i logiczna sekwencja analogiczna do przyjętej w poprzednim rozdziale, co zwiększa przejrzystość prowadzonych rozważań.

W recenzowanej monografii trafnie wskazano, że pewne zmiany wprowadzone ustawą wstrzymującą mogą niekorzystnie oddziaływać na sytuację prawną dzierżawców. Można by jednak nieco polemizować $\mathrm{z}$ zaprezentowanym w monografii stanowiskiem, że istotna z punktu widzenia oceny konstytucyjności ustawy wstrzymującej jest kwestia inwestycji (nakładów) poczynionych przez dzierżawców. Jak się wydaje, kwestia ta nie ma zasadniczo istotnego znaczenia dla praktyki obrotu. Regulacja kodeksowa, a często także postanowienia poszczególnych umów dzierżawy zapewniają ochronę prawną dzierżawcy, który poczynił nakłady na przedmiot dzierżawy. Nowelizacja stanu tego nie zmieniła. Wszelkie inwestycje i nakłady zostaną więc dzierżawcą nieruchomości rolnych zwrócone, o ile zostały dokonane zgodnie $z$ prawem. Dotyczy to zarówno nakładów koniecznych (art. 662 i $663 \mathrm{w}$ zw. $z$ art. 694 k.c.), jak i ulepszających (art. 676 w zw. z art. 694 k.c.), przy czym nieco inne są przesłanki. Warto dodać, że aktualne tendencje w orzecznictwie Sądu Najwyższego skłaniają się ku zapewnieniu silnej ochrony dzierżawcom dochodzącym zwrotu wartości nakładów ${ }^{13}$.

W opracowaniu wskazano na wątpliwości związane $z$ wprowadzonymi ustawą wstrzymującą zmianami, które umożliwiają Agencji zmniejszenie wielkości przedmiotu dzierżawy o 30\%. Wymusza to na dzierżawcy zainteresowanym dalszym trwaniem umowy wyrażenie zgody na ograniczenie wielkości pod sankcją utraty niektórych przysługujących dzierżawcy praw (np. pierwokupu). Trafnie zwrócono uwagę na negatywne konsekwencje zastosowania przez ustawodawcę wstecznej mocy ustawy wstrzymującej, co może to powodować ograniczenie zakresu prowadzenia inwestycji i naruszać pewności obrotu (zwłaszcza w przypadku umów dzierżawy zawartych na czas oznaczony). Autorzy słusznie wskazują, że wątpliwości

13 Szerzej na ten temat zob. w szczególności aktualne orzecznictwo: wyrok SN z 16 czerwca 2016 r., V CSK 655/15, Legalis nr 1482705; wyrok SN z 12 września 2013 r.; IV CSK 44/13, „Biuletyn SN - Izba Cywilna” 2015, nr 6, z glosą M. Drewka, „Studia Iuridica Toruniensia” 2015, T. 17, s. 289. 
może budzić ponadto brak jasnych kryteriów określających, które części nieruchomości mogą zostać przez Agencję wyłączone.

W doktrynie trafnie podnosi się również, że wątpliwości budzi kwestia, czy znowelizowane prawo pierwokupu przysługuje dzierżawcy również w przypadku sprzedaży udziału we współwłasności nieruchomości rolnej. Co więcej, zwraca się uwagę na wątpliwości interpretacyjne $\mathrm{w}$ zakresie określenia momentu powstania prawa pierwokupu przysługującego dzierżawcy. Nie jest jasne, czy powinno się liczyć 3 lata „trwania” czy też „wykonywania” umowy dzierżawy, co w praktyce może stanowić odmienne okoliczności ${ }^{14}$.

W konkluzji recenzowaną monografię należy ocenić pozytywnie, jako ważny głos w dyskusji nad kwestią konstytucyjności rozwiązań przyjętych przez ustawodawcę $\mathrm{w}$ ustawie wstrzymującej. W doktrynie można znaleźć obecnie zarówno głosy przychylne, jak i sceptyczne wobec wprowadzonej nowelizacji. Jak się wydaje, zgodzić się należy $z$ wyważonym stanowiskiem, że o ile cel wprowadzonych zmian nie jest pozbawiony słuszności, o tyle jakość legislacyjna ustawy wstrzymującej budzi wątpliwości.

\section{STRESZCZENIE}

Mariusz Bidziński, Marek Chmaj, Bogusław Uliasz,

Ustawa o wstrzymaniu sprzedaży nieruchomości rolnej Zasobu Własności Rolnej Skarbu Państwa - aspekt konstytucyjnoprawny, Wydawnictwo Adam Marszałek, Toruń 2017, ss. 247

Celem niniejszej recenzji jest podjęcie próby odniesienia się do mającej niedawno miejsce nowelizacji prawa spowodowanej ustawą o wstrzymaniu sprzedaży nieruchomości rolnej Zasobu Własności Rolnej Skarbu Państwa oraz nowelizacji kilku innych ustaw (tzw. ustawa wstrzymująca), przy czym dokonane w ujęciu prawa prywatnego. Wskazane odniesienie następuje w oparciu o monografię Ustawa o wstrzymaniu sprzedaży nieruchomości rolnej Zasobu Własności Rolnej Skarbu Państwa - aspekt konstytucyjnoprawny, opracowanej przez Mariusza Bidzińskiego, Marka

${ }^{14}$ Szerzej na ten temat zob. np.: J. Górecki, G. Matusik, Komentarz do art. 695, w: Kodeks cywilny. Komentarz. 
Chmaja oraz Bogusława Uliasza, konkretnie zaś poszczególnych tez w niej zawartych. Wspomniana monografia stanowi ważny głos w dyskusji nad kwestią konstytucyjności rozwiązań przyjętych przez ustawodawcę w ustawie wstrzymującej.

Słowa klucze: recenzja; ustawa o wstrzymaniu sprzedaży nieruchomości rolnej Zasobu Własności Rolnej Skarbu Państwa; ustawa wstrzymująca

\section{SUMMARY}

Mariusz Bidziński, Marek Chmaj, Bogusław Uliasz, Ustawa o wstrzymaniu sprzedaży nieruchomości rolnej Zasobu Własności Rolnej Skarbu Państwa - aspekt konstytucyjnoprawny, Wydawnictwo Adam Marszałek, Toruń 2017, ss. 247

The aim of this review is to undertake attempt of reference to the recent legislative amendment, provided by statue on withhold sale of agricultural real property of The National Treasury Resorces of Agrucultural Property and amendment of several other statutes (so - called withholding statue), whereby with regard to private law dimansion. The above - mentioned referance will be conducted on the ground of monograph: Ustawa o wstrzymaniu sprzedaży nieruchomości rolnej Zasobu Własności Rolnej Skarbu Państwa - aspekt konstytucyjnoprawny, elaborated by Mariusz Bidziński, Marek Chmaj and Bogusław Uliasz, while specifically it's particular scholar thesis. The said monograph represents a significant voice in discussion on complience of the withholding statue with the constitution.

Keywords: review; statue on withhold sale of agricultural real property of The National Treasury Resorces of Agrucultural Property; withholding statue

\section{BIBLIOGRAFIA}

Bieluk J., Ustawa o kształtowaniu ustroju rolnego. Komentarz, Warszawa 2016, wersja elektroniczna.

Borysiak W., w: Kodeks cywilny. Komentarz. Zobowiązania. Część szczegółowa, t. III B, red. K. Osajda, Warszawa 2017, wersja elektroniczna.

Drewek M., Glosa do wyroku Sądu Najwyższego z 5 października 2012 r., IV CSK 244/12, „Monitor Prawniczy” 2016, nr 14. 
Drewek M., Glosa do wyroku Sądu Najwyższego z 12 września 2013 r.; IV CSK 44/13, „Studia Iuridica Toruniensia” 2015, T. 17.

Dixon M., Modern Land Law, Oxon-New York, 2014.

Grykiel J., Ograniczenia obrotu nieruchomościami rolnymi oraz prawami udziałowymi $w$ spótkach po nowelizacji ustawy o kształtowaniu ustroju rolnego, „Monitor Prawniczy” 2016, nr 12.

Górecki J., Matusik G., w: Kodeks cywilny. Komentarz. Zobowiązania. Część szczegółowa, t. III B, red. K. Osajda, Warszawa 2017, wersja elektroniczna.

Ignatowicz J., Stefaniuk K., Prawo rzeczowe, Warszawa 2012.

Kępiński J., w: Kodeks cywilny, t. II: Komentarz. Art. 450-1088, red. M. Gutowski, Warszawa 2017, wersja elektroniczna.

Kuniewicz Z. i Słotwiński S., Glosa do wyroku Sądu Najwyższego z 5 października 2012 r., IV CSK 244/12, „Przegląd Prawa Rolnego” 2013, nr 2.

MacKenzie J. A., Philips M., Textbook on Land Law, Oxford 2014.

Morek, R. w: Kodeks cywilny. Komentarz. Zobowiazania. Część szczegółowa, t. III B, red. K. Osajda, Warszawa 2017, wersja elektroniczna

Smith R. J., Property Law - Longman Law Series, Harlow 2011.

Stelmachowski A., K. Zaradkiewicz, w: System prawa prywatnego. Prawo rzeczowe, t. III, red. E. Gniewek, Warszawa 2013.

Suchoń A., w: Kodeks cywilny, t. II: Komentarz. Art. 450-1088, red. M. Gutowski, Warszawa 2017, wersja elektroniczna.

Szymczyk P., Nabywanie nieruchomości rolnych $w$ świetle nowelizacji przepisów o kształtowaniu ustroju rolnego, cz. II, „Nieruchomości” 2017, nr 4. „Orzecznictwo Sądów Polskich” 2013, nr 10. 